\title{
Regulatory BCl RNA in cognitive control
}

\author{
Anna lacoangeli, ${ }^{1,2}$ Aderemi Dosunmu, ${ }^{1,2,5}$ Taesun Eom, ${ }^{1,2}$ Dimitre G. Stefanov, ${ }^{3}$ \\ and Henri Tiedge $\mathrm{e}^{1,2,4}$ \\ ${ }^{1}$ The Robert F. Furchgott Center for Neural and Behavioral Science; ${ }^{2}$ Department of Physiology and Pharmacology; ${ }^{3}$ Statistical Design \\ and Analysis, Research Division; ${ }^{4}$ Department of Neurology, State University of New York Downstate Medical Center, Brooklyn, \\ New York 11203, USA
}

\begin{abstract}
Dendritic regulatory $\mathrm{BCl}$ RNA is a non-protein-coding (npc) RNA that operates in the translational control of gene expression. The absence of $\mathrm{BCl}$ RNA in $\mathrm{BCl}$ knockout $(\mathrm{KO})$ animals causes translational dysregulation that entails neuronal phenotypic alterations including prolonged epileptiform discharges, audiogenic seizure activity in vivo, and excessive cortical oscillations in the $\gamma$ frequency band. Here we asked whether BCI RNA control is also required for higher brain functions such as learning, memory, or cognition. To address this question, we used odor/object attentional set shifting tasks in which prefrontal cortical performance was assessed in a series of discrimination and conflict learning sessions. Results obtained in these behavioral trials indicate that $\mathrm{BCl} \mathrm{KO}$ animals were significantly impaired in their cognitive flexibility. When faced with conflicting information sources, $\mathrm{BCl} \mathrm{KO}$ animals committed regressive errors as they were compromised in their ability to disengage from recently acquired memories even though recall of such memories was in conflict with new situational context. The observed cognitive deficits are reminiscent of those previously described in subtypes of human autism spectrum disorders.
\end{abstract}

Non-protein-coding (npc) RNAs are increasingly recognized as key determinants in the molecular regulation of cellular form and function. In the course of phylogenetic development, npc content in eukaryotic genomes has steadily increased to reach a representation of more than $95 \%$ in mammals (Taft et al. 2007). In humans, $<2 \%$ of the genomic capacity is dedicated to encode proteins (Mattick 2004; Taft et al. 2007) whereas a much larger percentage, $\sim 75 \%$, is allocated to encode npc RNA transcripts (Birney et al. 2007; Amaral et al. 2008; Djebali et al. 2012). It is assumed that many such transcripts are RNAs with regulatory functions, and that the need for RNA control has increased during evolution as a result of demands imposed by growing organismal complexities (Taft et al. 2007; Cordaux and Batzer 2009; Brosius 2014). Accordingly, enhanced RNA control has enabled increasing neural system complexities, culminating in mammalian brains (Cao et al. 2006; Salta and De Strooper 2012; Iacoangeli and Tiedge 2013).

A reliance on RNA regulation in brain raises an immediate and elemental question: what are the biological consequences if neuronal RNA control itself becomes dysregulated? Because adequate brain function is an essential underpinning of an organism's ability to interact successfully with its environment, we surmised that dysregulated RNA control in brain will result in behavioral inadequacies. To test this hypothesis, we used an animal model that lacks neuronal regulatory BC1 RNA (Skryabin et al. 2003; Lewejohann et al. 2004; Zhong et al. 2009; 2010). BC RNAs are a subtype of small cytoplasmic RNAs (scRNAs) that are delivered to synapto-dendritic domains in neurons (Tiedge et al. 1991, 1993; Chicurel et al. 1993; Muslimov et al. 1997, 2006,2011 ) and regulate protein synthesis by reversibly repressing translation initiation (Wang et al. 2002, 2005; Lin et al. 2008; Eom et al. 2011, 2014). In the BC1 knockout (KO) mouse, lack of BC1 RNA control causes increased cortical oscillations in

\footnotetext{
5Present address: Environmental Health \& Safety, Columbia University Medical Center, New York, NY 10032, USA. Corresponding author: henri.tiedge@downstate.edu Article is online at http://www.learnmem.org/cgi/doi/10.1101/Im.045427.117.
}

the $\gamma$ frequency range and neuronal hyperexcitability in the form of susceptibility to epileptogenesis in vitro and in vivo (Zhong et al. 2009, 2010; Iacoangeli and Tiedge 2013). These observations are suggestive of an imbalanced coordination of neural network excitation and inhibition resulting from translational dysregulation.

Neural discoordination has been proposed to cause impairments of cognitive control in how information is flexibly used in the presence of discordant information sources (Phillips and Silverstein 2003; Uhlhaas and Singer 2006, 2007; Lee et al. 2012). Here we investigate whether lack of BC1 RNA results in cognitive/behavioral impairment. We report that $\mathrm{BC} 1 \mathrm{KO}$ mice exhibit cognitive disability as they are unable to use stored information in a context-appropriate manner. Our work underlines the role of neuronal translational regulation in animal cognition and behavior (Gkogkas et al. 2010; Darnell 2011).

\section{Results}

\section{Repetitive behavior: self-grooming}

Informal observation of $\mathrm{BC} 1 \mathrm{KO}$ mice in their home cages alerted us to the possibility that these animals spontaneously engage in repetitive, excessive self-grooming. Stereotypic activity of this type has previously been associated with autism-like behavior (McFarlane et al. 2008; Silverman et al. 2010; Lai et al. 2014). We therefore conducted a systematic analysis of repetitive selfgrooming of $\mathrm{BC} 1 \mathrm{KO}$ animals.

Following habituation, self-grooming was examined over a period of $10 \mathrm{~min}$. We found (Fig. 1A) that $\mathrm{BC} 1 \mathrm{KO}$ animals engaged in significantly $(P=0.03)$ increased self-grooming activity, in comparison with age- and strain-matched wild-type (WT) animals.

(C) 2017 lacoangeli et al. This article is distributed exclusively by Cold Spring Harbor Laboratory Press for the first 12 months after the full-issue publication date (see http://learnmem.cshlp.org/site/misc/terms.xhtml). After 12 months, it is available under a Creative Commons License (AttributionNonCommercial 4.0 International), as described at http://creativecommons. org/licenses/by-nc/4.0/. 
A

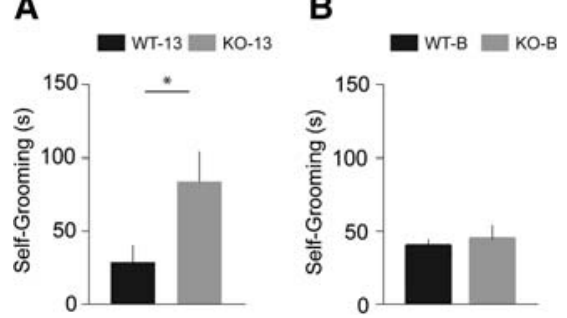

Figure 1. Self-grooming of $\mathrm{BC} 1 \mathrm{KO}$ animals. $(A) \mathrm{KO}-13$ mice exhibited elevated self-grooming activity in comparison with WT-13 mice $(P=$ 0.03 ). $n=12$ for each group. (B) No significant difference was detected between self-grooming activities of KO-B and WT-B animals $(P=0.67)$. $n=20$ for each group.

The above work was performed with $\mathrm{BC} 1 \mathrm{KO}$ animals of line 13 which were of the same genetic background (mixed C57BL/6J and $129 \mathrm{X} 1 / \mathrm{SvJ}$ ) as those used in previous publications (Lewejohann et al. 2004; Zhong et al. 2009, 2010). However, mouse behavior is known to be impacted by animal strain type (Colacicco et al. 2002; Yoshiki and Moriwaki 2006; Bryant et al. 2008; Ishimura et al. 2014; Lei et al. 2014). We therefore tested selfgrooming behavior in a second strain of $\mathrm{BC} 1 \mathrm{KO}$ animals, one that had been backcrossed into the C57BL/6J background (Materials and Methods). Figure $1 \mathrm{~B}$ shows that these animals did not exhibit excessive self-grooming, in comparison with age- and strain-matched WT animals $(P=0.67)$.

The above results indicate that (i) lack of regulatory BC1 RNA in line $13 \mathrm{BC} 1 \mathrm{KO}$ animals gives rise to repetitive and stereotyped behavior, and that (ii) the genetic background of C57BL/6J BC1 $\mathrm{KO}$ animals attenuates this phenotype. All subsequent experiments were therefore performed with animals of both background strains in parallel. We will in the following refer to line $13 \mathrm{BC} 1 \mathrm{KO}$ animals as $\mathrm{KO}-13$ mice and to $\mathrm{C} 57 \mathrm{BL} / 6 \mathrm{~J} \mathrm{BC} 1 \mathrm{KO}$ animals as $\mathrm{KO}-\mathrm{B}$ mice (B for black). WT-13 and WT-B will be the terms used for the respective WT counterpart animals.

\section{Cognitive flexibility}

$\gamma$-Frequency rhythms have been linked to prefrontal cortical functionality and cognitive flexibility (Cho et al. 2006, 2015), and disturbances in such rhythms have been implicated in autism spectrum disorders (ASD) (Uhlhaas and Singer 2012). Since lack of BC1 RNA results in aberrant $\gamma$ synchrony (Zhong et al. 2009), the question arises whether cognitive flexibility is impaired in BC1 KO animals. A modified attentional set shift task (ASST) protocol (Materials and Methods) was adopted to address this question. Cognitive flexibility has been associated with prefrontal cortical areas, in particular the orbitofrontal cortex (OFC) (Eichenbaum et al. 1983; McAlonan and Brown 2003; Garner et al. 2006; Schoenbaum et al. 2009; D'Cruz et al. 2013; Tait et al. 2014), and the ASST has previously been used to assess prefrontal cortical function and cognitive flexibility (Brown and Bowman 2002; Garner et al. 2006; Tait et al. 2014).

The ASST protocol adopted here features a series of learning sessions, organized in four sequential phases, to dissect simple discrimination learning, compound discrimination learning, and conflict learning performance. In each phase, animals had to develop and apply a context-appropriate response strategy; once this had been achieved, they were presented with a new scenario that was in conflict with the previously acquired strategy. In the initial learning sessions, the reward-relevant dimension (odor) remained constant although reward-predictive stimuli within that dimension were subject to change (intradimensional shift, IDS; see Table 1).

\section{Phase 1: simple discrimination learning, compound discrimination learning} 1, and conflict learning 1

Three learning sessions were scheduled in Phase 1 of the ASST protocol: Simple Discrimination Learning, Compound Discrimination Learning 1, and Conflict Learning 1. For all trials, each of the two bowls in the testing area displayed three types of sensory stimuli (three "dimensions"): digging medium, odor of the digging medium, and texture of the outer surface of the bowl. A dimension could be reward-relevant or not, a specific stimulus in a reward-relevant dimension could be rewardpredictive or not, and such a stimulus could change between sessions from being reward-predictive to nonpredictive and vice versa. For each animal, we recorded the number of incorrect choices that were made before criterion was reached (errors to criterion, ETC) and the number of trials that were needed to reach criterion (trials to criterion, TTC) (see Materials and Methods). Genotype (KO versus WT) and strain (line 13 versus line B) were examined as predictor variables of animal performance. The Cox proportional hazards regression model (Jahn-Eimermacher et al. 2011; see Materials and Methods) was used to analyze the data obtained.

In the initial session of Phase 1, Simple Discrimination Learning, $\mathrm{KO}(\mathrm{KO}-13$ and KO-B) mice were significantly impaired, in comparison with WT (WT-13 and WT-B) mice (Fig. 2, left panels: Cox regression analysis, $\mathrm{HR}=0.63,95 \%$ CI $0.41-0.96, P=$ 0.03). Line 13 (KO-13 and WT-13) animals performed significantly better than line $\mathrm{B}$ animals (KO-B and WT-B) $(\mathrm{HR}=1.96,95 \% \mathrm{CI}$ $1.21-3.18, P=0.007$ ). (This initial simple discrimination session is sometimes considered an extension of the habituation phase; Cao et al. 2012) In the subsequent session, Compound Discrimination Learning 1 , no differences were observed between performances of $\mathrm{KO}$ and WT animals (Fig. 2, center panels: $\mathrm{HR}=0.70$, 95\% CI $0.47-1.06, P=0.09$ ). Line 13 animal performance was again significantly better than that of line $B$ animals $(H R=1.52$, $95 \%$ CI 1.02-2.26, $P=0.04$ ). Thus, in both simple and compound discrimination learning, KO-13 animals performed significantly better than KO-B animals and WT-13 animals performed significantly better than WT-B animals. The data indicate that animal strain type impacted performance.

In the following session Conflict Learning 1 (in which cinnamon had replaced sage as the reward-predictive stimulus; Table 1), KO mice were significantly impaired in comparison with WT animals. KO animals kept digging for rewards in the unbaited sagescented bowl even after having been confronted with negative feedback. As a result, the incorrect-response rate (ETC) of $\mathrm{KO}$ mice was increased in comparison with that of WT mice, and KO mice needed a higher number of TTC than did WT mice (Fig. 2, right panels). Cox regression analysis confirmed that the KO genotype was associated with significantly higher numbers of ETC and TTC than the WT genotype $(\mathrm{HR}=0.40,95 \% \mathrm{CI}$ $0.22-0.73, P=0.003)$, indicating impairment of $\mathrm{KO}$ (KO-13 and $\mathrm{KO}-\mathrm{B}$ ) animals in conflict learning. A strain effect was again apparent as line 13 animals performed significantly better than line $B$ animals ( $\mathrm{HR}=1.91,95 \% \mathrm{CI} 1.03-3.53, P=0.04)$. As before, the line 13 versus line B performance difference was evident with both $\mathrm{KO}$ and $\mathrm{WT}$ animals.

The above data indicate that $\mathrm{BC} 1 \mathrm{KO}$ animals performed similarly to WT animals in the Compound Discrimination Learning session. Thus, learning and memory (i.e., the recall of stored information) were not impaired per se at this point. However, BC1 KO animals performed poorly when subsequently confronted with a scenario that conflicted with previously acquired memories (Conflict Learning session). What appears impaired, therefore, is the situation-appropriate application of stored information, i.e., cognitive flexibility in the control of memories. 
Table 1. The nine learning sessions of the ASST protocol

\begin{tabular}{|c|c|c|c|c|c|}
\hline \multirow{2}{*}{$\frac{\text { Session }}{\text { SD Learning }}$} & \multirow{2}{*}{$\begin{array}{c}\text { Phase } \\
1\end{array}$} & \multirow{2}{*}{$\frac{\text { Day }}{1}$} & \multirow{2}{*}{$\begin{array}{l}\text { Dimension } \\
\text { Odor } \\
\text { Medium } \\
\text { Texture }\end{array}$} & \multicolumn{2}{|c|}{ Stimulus pairing (reward-predictive stimulus*) } \\
\hline & & & & $\begin{array}{l}\text { Sage* } \\
\text { Aspen bedding } \\
\text { Plastic wrap }\end{array}$ & $\begin{array}{l}\text { Cinnamon } \\
\text { Aspen bedding } \\
\text { Plastic wrap }\end{array}$ \\
\hline CD Learning 1 & 1 & 2 & $\begin{array}{l}\text { Odor } \\
\text { Medium } \\
\text { Texture }\end{array}$ & $\begin{array}{l}\text { Sage* } \\
\text { Aspen bedding } \\
\text { Plastic wrap }\end{array}$ & $\begin{array}{l}\text { Cinnamon } \\
\text { Moss } \\
\text { Bubble wrap }\end{array}$ \\
\hline Conflict Learning 1 & 1 & 2 & $\begin{array}{l}\text { Odor } \\
\text { Medium } \\
\text { Texture }\end{array}$ & $\begin{array}{l}\text { Sage } \\
\text { Aspen bedding } \\
\text { Plastic wrap }\end{array}$ & $\begin{array}{l}\text { Cinnamon* } \\
\text { Moss } \\
\text { Bubble wrap }\end{array}$ \\
\hline CD Learning 2 (IDS) & 2 & 2 & $\begin{array}{l}\text { Odor } \\
\text { Medium } \\
\text { Texture }\end{array}$ & $\begin{array}{l}\text { Cumin* } \\
\text { Gravel } \\
\text { Wax paper }\end{array}$ & $\begin{array}{l}\text { Rosemary } \\
\text { Pellets } \\
\text { Aluminum foil }\end{array}$ \\
\hline Conflict Learning 2 (IDS) & 2 & 2 & $\begin{array}{l}\text { Odor } \\
\text { Medium } \\
\text { Texture }\end{array}$ & $\begin{array}{l}\text { Cumin } \\
\text { Gravel } \\
\text { Wax paper }\end{array}$ & $\begin{array}{l}\text { Rosemary* } \\
\text { Pellets } \\
\text { Aluminum foil }\end{array}$ \\
\hline CD Learning 3 (IDS) & 3 & 3 & $\begin{array}{l}\text { Odor } \\
\text { Medium } \\
\text { Texture }\end{array}$ & $\begin{array}{l}\text { Oregano* } \\
\text { Packing peanuts } \\
\text { Smooth cardboard }\end{array}$ & $\begin{array}{l}\text { Nutmeg } \\
\text { Shredded paper } \\
\text { Cloth }\end{array}$ \\
\hline Conflict Learning 3 (IDS) & 3 & 3 & $\begin{array}{l}\text { Odor } \\
\text { Medium } \\
\text { Texture }\end{array}$ & $\begin{array}{l}\text { Oregano } \\
\text { Packing peanuts } \\
\text { Smooth cardboard }\end{array}$ & $\begin{array}{l}\text { Nutmeg* } \\
\text { Shredded paper } \\
\text { Cloth }\end{array}$ \\
\hline CD Learning 4 (EDS) & 4 & 3 & $\begin{array}{l}\text { Odor } \\
\text { Medium } \\
\text { Texture }\end{array}$ & $\begin{array}{l}\text { Thyme } \\
\text { Perlite* } \\
\text { Fine sandnaner }\end{array}$ & $\begin{array}{l}\text { Cloves } \\
\text { Sand }\end{array}$ \\
\hline Conflict Learning 4 (EDS) & 4 & 3 & $\begin{array}{l}\text { Odor } \\
\text { Medium } \\
\text { Texture }\end{array}$ & $\begin{array}{l}\text { Thyme } \\
\text { Perlite } \\
\text { Fine sandpaper }\end{array}$ & $\begin{array}{l}\text { Cloves } \\
\text { Sand* } \\
\text { Coarse sandoaner }\end{array}$ \\
\hline
\end{tabular}

SD, simple discrimination; CD, compound discrimination. Intradimensional shift (IDS) was used in Phases 2 and 3 , extradimensional shift (EDS) in Phase 4. In any given session, a reward-predictive stimulus (indicated by asterisk) was never used in conjunction with the same stimuli of the reward-irrelevant dimensions in more than two consecutive trials.

\section{Phase 2: compound discrimination learning 2 and conflict learning 2 (IDS)}

After completion of Phase 1, mice were presented with a new scenario in which the stimuli in all three dimensions were novel ("all change scenario"). Odor remained the reward-relevant dimension but stimuli were switched from the sage-cinnamon pairing to a cumin-rosemary pairing. Digging medium was changed from an aspen bedding-moss to a gravel-pellets pairing, and bowl texture from a plastic wrap-bubble wrap to a wax paper-aluminum foil pairing (IDS) (see Table 1).

As shown in Figure 3 (left panels), performance in Phase 2 Compound Discrimination Learning sessions did not significantly differ between the two genotypes ( $\mathrm{KO}$ versus $\mathrm{WT}, \mathrm{HR}=$ $0.92,95 \%$ CI $0.61-1.38, P=0.68$ ) or between the two strains (line 13 versus line $\mathrm{B}, \mathrm{HR}=1.04,95 \% \mathrm{CI} 0.67-1.62, P=0.86$ ). In the Compound Discrimination Learning 2 session, animals from all groups rapidly learned that the new reward-predictive odor was cumin but not rosemary (and no longer sage). However, $\mathrm{KO}$ animals were impaired in the subsequent Conflict Learning 2 session (Fig. 3, right panels), in comparison with WT animals ( $\mathrm{HR}=0.38,95 \% \mathrm{CI} 0.21-0.71, P=0.002)$. When the reward-predictive odor was switched from cumin to rosemary, $\mathrm{KO}$ (KO-13 and KO-B) animals continued to behave in a manner consistent with what they had learned in the previous session, i.e., that cumin was predicting a reward, but inconsistent with what they experienced in the current session, i.e., that cumin was nonpredictive. ETC/TTC did not significantly differ between line 13 mice and line B mice $(\mathrm{HR}=1.50,95 \% \mathrm{CI} 0.87-2.59, P=$ $0.15)$,

In summary, Phase 2 revealed persistent deficits in the ability of $\mathrm{BC} 1 \mathrm{KO}$ animals to modify their selection strategy in response to changing contingencies. Both strains of $\mathrm{BC} 1 \mathrm{KO}$ animals were impaired in their cognitive competence to adjust to a novel stimulus-reward association, despite the fact that they were indistinguishable from WT animals in the Compound
Discrimination Learning 2 session just preceding the Conflict Learning 2 session.

Phase 3: compound discrimination learning 3 and conflict learning 3 (IDS)

We next asked whether cognitive flexibility impairments of BC1 KO animals could be overcome by extended additional training. To this end, a further training session (held the following day) assessed cognitive performance in a third round of Compound Discrimination Learning and Conflict Learning sessions. In Compound Discrimination Learning 3, all stimuli were changed (Table 1). Odor remained the reward-relevant dimension (IDS) in which oregano (in an oregano-nutmeg pairing) was now reward-predictive. Medium was switched to a packing peanutsshredded paper pairing, texture to a smooth cardboard-cloth pairing.

As shown in Figure 4 (left panels), KO and WT animals performed comparably in the Compound Discrimination Learning 3 session (HR $=0.74,95 \%$ CI $0.51-1.08, P=0.12)$. The two strains (line 13 and line B) were also not significantly different from each other in this session ( $\mathrm{HR}=1.35,95 \% \mathrm{CI} 0.90-2.02, P=0.14)$. For the subsequent Conflict Learning session (Fig. 4, right panels), a significant interaction $(P=0.017)$ was present in the Cox regression model between the two predictors, genotype and strain. This interaction indicated that the genotype difference (KO versus WT) was not uniform in the two lines (13 versus B). Thus, while KO-13 mice were significantly impaired, in comparison with WT-13 mice (Fig. 4, right panels, line 13: HR $=0.29,95 \% \mathrm{CI}$ 0.11-0.71, $P=0.007$, KO-B mice performed similarly to WT-B mice (Fig. 4 , right panels, line $\mathrm{B}: \mathrm{HR}=\mathrm{HR}=1.15$, 95\% CI $0.58-$ $2.28, P=0.69)$. It appears that extended training improved conflict learning performance of KO-B but not of KO-13 animals, with the latter but not the former continuing to be significantly impaired. 
A

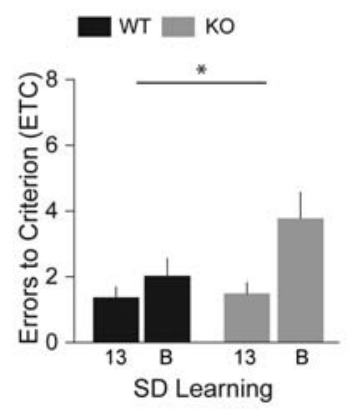

B

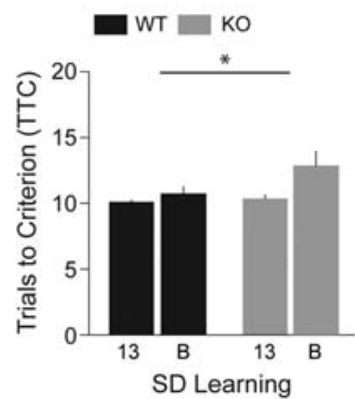

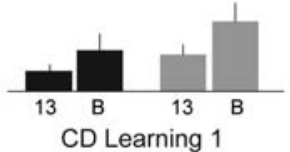

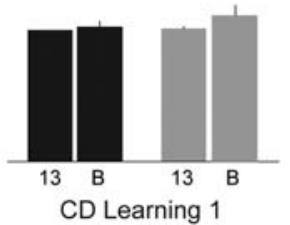

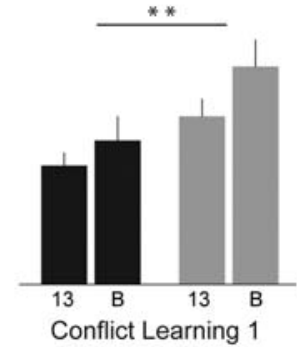

Conflict Learning 1

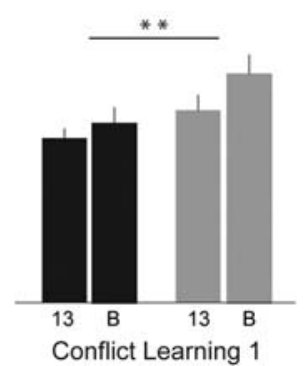

Figure 2. Simple discrimination (SD) Learning, Compound Discrimination (CD) Learning 1, and Conflict Learning 1 in ASST Phase 1. Numbers of ETC $(A)$ and TTC $(B)$ were recorded. BC1 KO animals were significantly impaired in Simple Discrimination Learning (left panels), in comparison with WT animals ( $\mathrm{HR}=0.63,95 \% \mathrm{Cl} 0.41-0.96, P=0.03)$. Line 13 animals performed better than line $B$ animals $(H R=1.96,95 \% \mathrm{Cl} 1.21-3.18, P=0.007$, not shown). In Compound Discrimination Learning (center panels), $\mathrm{KO}$ and WT animals performed comparably ( $\mathrm{HR}=0.70,95 \% \mathrm{Cl} 0.47-1.06$, $P=0.09)$. Again, however, line 13 animals outperformed line $B$ animals $(H R=1.52,95 \% \mathrm{Cl} 1.02$ 2.26, $P=0.04$, not shown). In the Conflict Learning session (right panels), numbers of ETC and TTC were significantly higher for $\mathrm{KO}$ than for $\mathrm{WT}$ mice $(\mathrm{HR}=0.40,95 \% \mathrm{Cl} 0.22-0.73, P=0.003)$. Line 13 mice performed better than line $B$ mice ( $H R=1.91,95 \% \mathrm{Cl} 1.03-3.53, P=0.04$; not shown). Thus, in Simple Discrimination Learning, in Compound Discrimination Learning, and in Conflict Learning, KO-13 animals performed significantly better than KO-B animals and WT-13 animals performed significantly better than WT-B animals. $n=8$ for each group.

In Conflict Learning session 3 (Fig. 4, right panels), WT-B animal performance was significantly inferior to WT-13 animal performance $(\mathrm{HR}=0.45,95 \% \mathrm{CI} 0.23-0.89, P=0.02)$. Therefore, the apparent improvement of KO-B animals in Phase 3 conflict learning may at least in part be attributable to the fact that line $\mathrm{B}$ animals, including WT-B animals, display a generally lower level of cognitive performance than line 13 animals (see Discussion).

\section{Phase 4: extradimensional shift (EDS)}

Results from the Phase 3 learning sessions can be interpreted to indicate that performance of KO-B mice had improved while that of KO-13 mice remained impaired, in comparison with respective WT animals. To examine whether performance improved with further practice, we performed extradimensional shift sessions. In these trials (Fig. 5), in which textures of the digging media, rather than their odors, had become reward-relevant, KO mice performed similarly to WT mice both in compound discrimination learning (Fig. 5, left panels: $\mathrm{HR}=1.28, \mathrm{CI} 0.91-1.81, P=0.16$ ) and in conflict learning (Fig. 5, right panels: $\mathrm{HR}=1.06,95 \%$ CI 0.59-1.90, $P=0.84$ ). Cox regression analysis of ETC and TTC of the two strains (line 13 versus line B) revealed that in the Compound Discrimination Learning and in the Conflict Learning sessions, line 13 animals (both KO and WT) performed significantly better than the respective line B animals (Fig. 5, left panels, Compound
Discrimination Learning: $\mathrm{HR}=2.14$, 95\% CI 1.39-3.29, $P=0.001$; right panels, Conflict Learning: $\mathrm{HR}=1.96,95 \%$ CI 1.06-3.63, $P=0.03$ ).

\section{Learning curve analysis}

To examine the ability of $\mathrm{KO}$ animals to overcome conflict learning deficits with extended practice, we subjected the data to learning curve analysis (Fig. 6). We used the Jonckheere-Terpstra test to establish any statistically significant trend in the performance of the four animal groups through the four phases. The median number of ETC committed by KO-13 animals decreased significantly across the four phases of conflict learning (Fig. 6 , red triangles, $P=0.03$ ). The same trend was observed for KO-B animal performance as the median number of ETC committed across the four phases of conflict learning decreased significantly (Fig. 6 , red squares, $P=0.005$ ). In contrast, both WT-13 and WT-B animals performed consistently well through the four phases as no significant improvements were observed $(P=0.08$ and $P=$ 0.71 , respectively). We conclude that $\mathrm{KO}$ animals of both strains had improved their conflict learning performance by the time Phase 4 had been completed. Improved conflict learning performance as a result of prolonged training, i.e., through practice, has been described as a distinctive feature of prefrontal corticalmediated cognitive competence (Dias et al. 1997; Schoenbaum et al. 2002).

\section{Types of error}

Errors made in conflict learning trials are typically classified as perseverative or regressive (Ragozzino et al. 2002; Ragozzino 2007; $D^{\prime}$ Cruz et al. 2013). The former type of error is committed when an animal repeatedly and consecutively selects the previously rewarded but now incorrect response before it switches to a new, correct response. A regressive error, on the other hand, is committed when an animal, after having chosen a correct response at least once, regresses back to choosing the previously rewarded but now incorrect response.

For each of the four animal groups (KO-13, WT-13, KO-B, and WT-B), we analyzed the types of error committed in Conflict Learning sessions 1 and 2 combined (Fig. 7A,B). We found that $\mathrm{KO}-13$ mice did not significantly differ from WT-13 mice in the number of perseverative errors committed (Fig. 7A, $P=0.87$ ). However, KO-13 animals made significantly more regressive errors than WT-13 animals (Fig. 7A, $P=0.02$ ). Similarly, there was no significant difference in the number of perseverative errors committed by $\mathrm{BC} 1 \mathrm{KO}-\mathrm{B}$ mice versus WT-B mice (Fig. 7B, $P=0.72$ ) but $\mathrm{BC} 1 \mathrm{KO}-\mathrm{B}$ mice committed a significantly higher number of regressive errors than WT-B mice (Fig. $7 \mathrm{~B}, P=0.02$ ).

Regressive behavior, as expressed by $\mathrm{BC} 1 \mathrm{KO}$ mice, indicates that even though a new and context-appropriate strategy has been acquired and has successfully been applied, animals were unable to maintain this strategy but rather reverted to the previously 
A

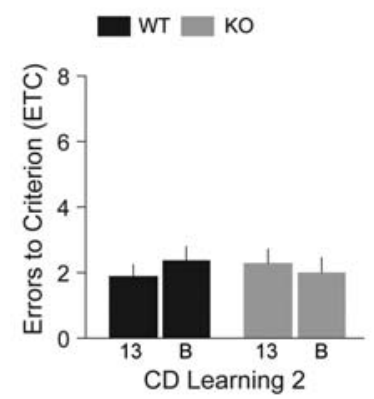

B

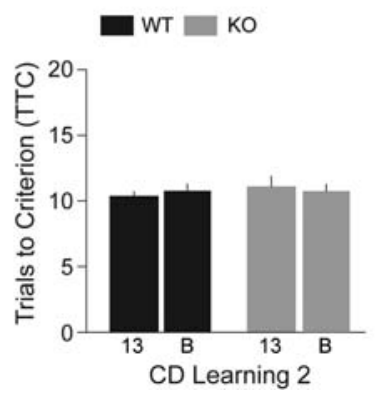

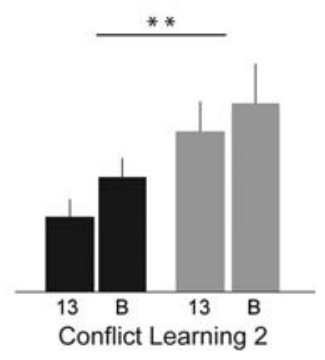

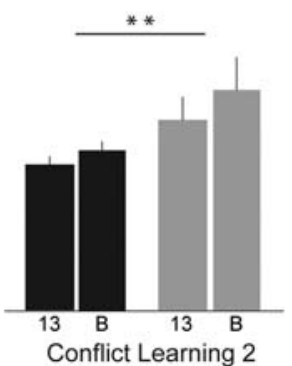

Figure 3. Compound Discrimination (CD) Learning 2 and Conflict Learning 2 (Phase 2, IDS). Numbers of ETC $(A)$ and TTC $(B)$ were recorded. Following a change of all stimuli (Table 1), KO and WT mice performed comparably in session Compound Discrimination Learning 2 (left panels, $\mathrm{HR}=0.92,95 \% \mathrm{Cl} 0.61-1.38, P=0.68)$. However, $\mathrm{KO}$ mice displayed significant deficits in session Conflict Learning 2 (right panels, $\mathrm{HR}=0.38,95 \% \mathrm{Cl} 0.21-0.71, P=0.002$ ) as they committed more ETC and required more TTC than WT mice. There was no significant difference between the performance of line 13 animals and line B animals in Compound Discrimination Learning and in Conflict Learning $(\mathrm{HR}=$ $1.04,95 \% \mathrm{Cl} 0.67-1.62, P=0.86$ and $\mathrm{HR}=1.50,95 \% \mathrm{Cl} 0.87-2.59$, $P=0.15$, respectively; not shown). KO-13 and WT-13 groups: $n=10$ each; KO-B and WT-B groups: $n=8$ each.

acquired but now context-inappropriate strategy (Fig. 7C). Similar regressive behavior, with increased numbers of regressive but not of perseverative errors, has been observed in ASD patients ( $D^{\prime} \mathrm{Cruz}$ et al. 2013).

\section{Spontaneous alternation}

To address the question whether spatial memory or cognition was impacted in $\mathrm{BC} 1 \mathrm{KO}$ animals, we used the T-maze task to examine spontaneous alternation (Lalonde 2002). The task relies on the innate spatial curiosity of rodents who, after having visited one of two maze arms in a first trial, will in a subsequent trial tend to choose the other, not yet visited arm (Deacon and Rawlins 2006). Performance in this task reflects formation and flexible use of spatial working memory and is strongly dependent on hippocampal functionality (Rawlins and Olton 1982; Deacon and Rawlins 2006).

In the sample phase of the task, a WT or KO mouse was placed in the start arm of the T-shaped maze and was allowed to select one of the two goal arms. In the subsequent choice phase, the same animal was again placed in the start arm and allowed to make a second selection of one of the two goal arms. Entrance into the previously not visited goal arm was recorded as a spontaneous alternation. Results from these experiments (Fig. 8) revealed no significant differences in spontaneous alternations, as percentage of total number of goal arm choices, between $\mathrm{KO}-13$ and WT-13 animals $(P=0.64)$ or between KO-B and WT-B animals $(P=0.75)$. In addition, no significant differences were apparent between the spontaneous alternation performance of line 13 animals and line $\mathrm{B}$ animals $(P=0.10)$.

The data indicate that spatial working memory performance, in particular also spontaneous spatial alternation, is not impaired in animals lacking regulatory BC1 RNA. It thus appears, and will be examined in context in the Discussion, that in the absence of BC1 RNA, prefrontal cortical associative cognition is compromised whereas hippocampal spatial cognition remains spared.

\section{Discussion}

RNA regulation is increasingly recognized as contributing to the functional management of complex biological systems (Taft et al. 2007; Mattick 2009; Brosius 2014). RNA control of gene expression in brain, we posit, provides a mechanism for animals to appropriately adjust their behavior to changing external contingencies, thus shaping the dynamic interplay between genetic setup and sensory input that is received from the environment.

\section{A}

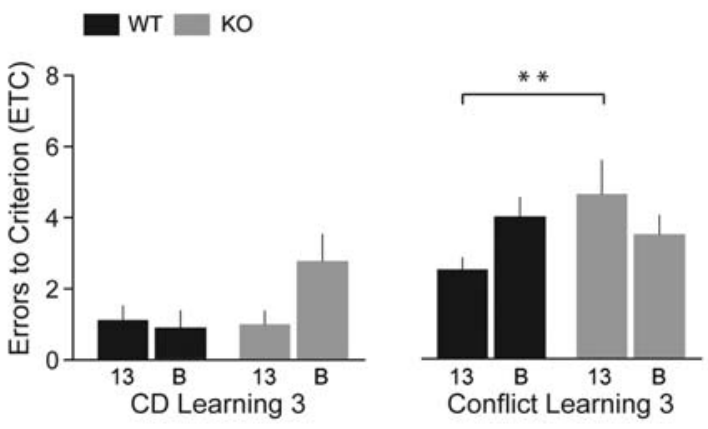

B

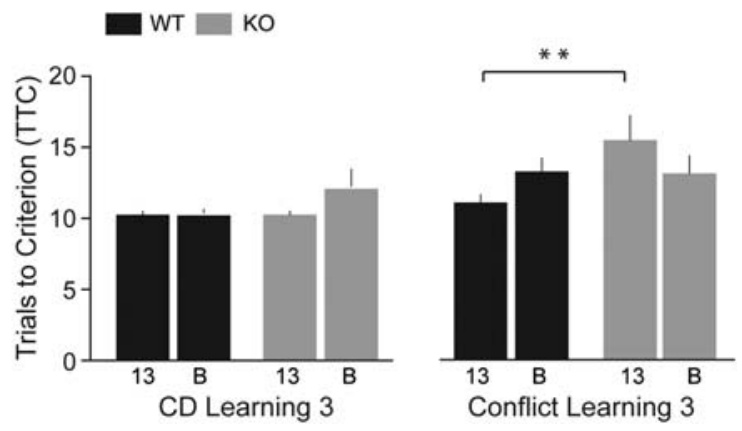

Figure 4. Compound Discrimination (CD) Learning 3 and Conflict Learning 3 (Phase 3 , IDS). Numbers of ETC $(A)$ and TTC $(B)$ were recorded. KO and WT animals performed comparably in the Compound Discrimination Learning session (left panels, $\mathrm{HR}=0.74,95 \% \mathrm{Cl} 0.51-$ $1.08, P=0.12)$. There was also no significant difference between the two strains in this session $(\mathrm{HR}=1.35,95 \% \mathrm{Cl} 0.90-2.02, P=0.14$; not shown). However, persistently impaired cognitive flexibility of BC1 KO-13 mice was revealed in Conflict Learning session 3 (right panels, $\mathrm{HR}=0.29,95 \% \mathrm{Cl} 0.11-0.71, P=0.007)$ : more ETC were committed and more TTC were required by KO-13 mice than by WT-13 mice. KO-B and WT-B animals performed similarly in the Conflict Learning session $(\mathrm{HR}=1.15,95 \% \mathrm{Cl} 0.58-2.28, P=0.69)$. Performance of WT-B mice was significantly inferior to that of WT-13 mice in the Conflict Learning session ( $\mathrm{HR}=0.45,95 \% \mathrm{Cl} 0.23-0.89, P=0.02$; not shown). A significant interaction of genotype versus strain $(P=0.017)$ is noted. $n=8$ for each group. 
A

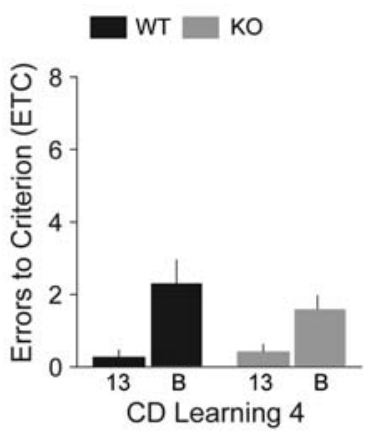

B

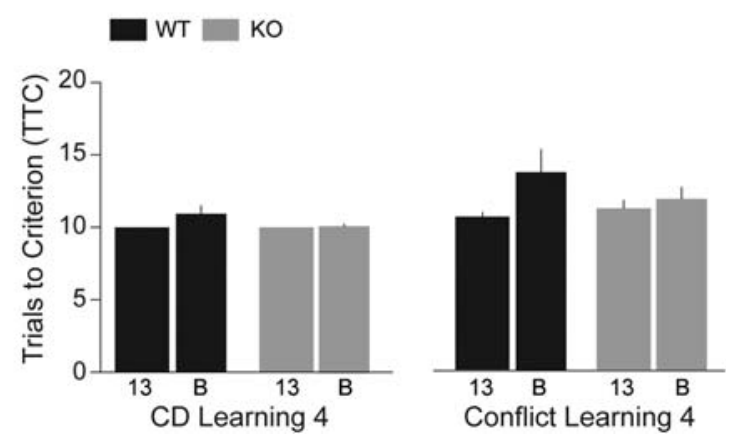

Figure 5. Compound Discrimination (CD) Learning 4 and Conflict Learning 4 (Phase 4, EDS). Numbers of ETC $(A)$ and TTC $(B)$ were recorded. KO mice performed comparably to WT mice in EDS Compound Discrimination Learning and Conflict Learning sessions (left panels $\mathrm{HR}=$ $1.28, \mathrm{Cl} 0.91-1.81, P=0.16$; right panels $\mathrm{HR}=1.06,95 \% \mathrm{Cl} 0.59$ $1.90, P=0.84)$. Line 13 mice performed significantly better than line $B$ mice in both Compound Discrimination Learning and Conflict Learning sessions $(\mathrm{HR}=2.14,95 \% \mathrm{Cl} 1.39-3.29, P=0.001$ and $\mathrm{HR}=1.96$, $95 \% \mathrm{Cl} 1.06-3.63, P=0.03$, respectively; not shown). $n=7$ for each group.

Here we address the role of regulatory BC1 RNA in the flexible, context-appropriate adjustability of animal behavior.

Neuronal BC1 RNA, located in synapto-dendritic microdomains, controls protein synthesis in an activity-dependent manner (Eom et al. 2014). In the basal steady-state, BC1 RNA serves as a translational repressor via interactions with eukaryotic initiation factors (eIFs) 4A and 4B (Wang et al. 2002, 2005; Lin et al. 2008; Eom et al. 2011, 2014). In translation initiation, these two factors promote recruitment of $40 \mathrm{~S}$ small ribosomal subunits to mRNAs with complex $5^{\prime}$ untranslated regions (Dmitriev et al. 2003; Pestova et al. 2007; Shahbazian et al. 2010) which, in neurons, are prominently represented among dendritic mRNAs (A. Iacoangeli and $\mathrm{H}$. Tiedge, unpubl.). Under basal conditions, such recruitment is inhibited by binding of BC1 RNA to eIFs $4 \mathrm{~A}$ and 4B, resulting in factor inactivation (Eom et al. 2011, 2014). Upon neuronal stimulation and receptor activation, BC1 RNA control switches from repressive to permissive: rapid dephosphorylation of eIF4B at serine 406 causes dissociation of BC1 RNA-factor complexes which, as a consequence of factor release, enables $40 \mathrm{~S}$ subunit recruitment and translation initiation (Eom et al. 2011, 2014).

Lack of BC1 RNA in the BC1 $\mathrm{KO}$ animal model results in increased synthesis of select synaptic proteins and in a number of phenotypic manifestations that suggest a role of the RNA in the maintenance of synaptic excitation-repression balances (Zhong et al. 2009, 2010; Iacoangeli and Tiedge 2013). Such manifesta- tions include (i) neuronal hyperexcitability, as evidenced by a propensity for prolonged, epileptiform discharges in CA3 hippocampal pyramidal cells, (ii) susceptibility to sound-induced (audiogenic) seizures in vivo, and (iii) excessive cortical oscillations in the $\gamma$ frequency range. Synchronized $\gamma$-band oscillations have been described as underlying cortical mechanisms of cognition and perception, and aberrant $\gamma$ synchrony has been associated with cognitive deficits (Uhlhaas and Singer 2006, 2012; Fries 2009). Specifically, $\gamma$ oscillations have been linked to prefrontal cortical network functionality and cognitive flexibility (Cho et al. 2006, 2015), and impaired $\gamma$ synchrony and reduced cognitive flexibility may contribute to ASD phenotypes (Uhlhaas and Singer 2012; D'Cruz et al. 2013). These considerations, together with the observation that $\mathrm{BC} 1 \mathrm{KO}$ animals engage in excessive repetitive behavior, spurred our interest in the question whether lack of BC1 RNA control would find expression in impaired cognitive abilities.

We adopted the ASST protocol (Tait et al. 2014) for an assessment of animal cognition in the absence of BC1 RNA. Positive reinforcement (a food reward) was used to evaluate simple discrimination learning, compound discrimination learning, and conflict learning. Each of the four learning phases concluded with a conflict learning session in which a newly changed reward contingency was in conflict with information that the animal had previously acquired. The most salient data resulting from this series of behavioral tests show that both strains of $\mathrm{BC} 1 \mathrm{KO}$ animals were significantly impaired in conflict learning, in comparison with their WT counterparts. BC1 KO animals exhibited cognitive inflexibility as they continued to operate in the framework of the previously acquired information although recall of this memory was now in conflict with the novel situation. Since such inflexibility of BC1 KO animals was directly preceded and followed by adequate, WT-like performance in Compound Discrimination Learning sessions, we conclude that the ASST-diagnosed impairments are indicative of deficits in the cognitive control of memory, i.e., its judicious, situation-responsive application.

Cognitive flexibility is an essential underpinning of adaptive decision-making, and a number of brain regions, in particular prefrontal cortical regions, have been implicated in its maintenance. For instance, damage to the OFC has been reported to result in impaired conflict learning performance (Eichenbaum et al. 1983; Ragozzino 2007; Schoenbaum et al. 2009; Gruber et al. 2010; Tait et al. 2014). The OFC has been proposed to signal outcome expectancies on the basis of previous experience, and it is possible that interactions between the OFC and other brain regions, such

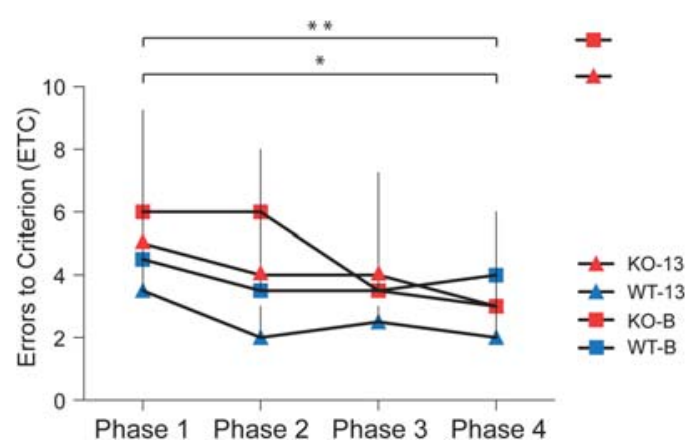

Figure 6. Conflict learning curve analysis of the median ETC (including interquartile ranges, IQR) for the four animal groups. Conflict learning performance of both KO-13 animals and KO-B animals improved significantly across the four phases $(P=0.03$ and $P=0.005$, respectively) whereas no such improvement was apparent for the performance of WT-13 or WT-B animals ( $P=0.08$ and $P=0.71$, respectively). 
A
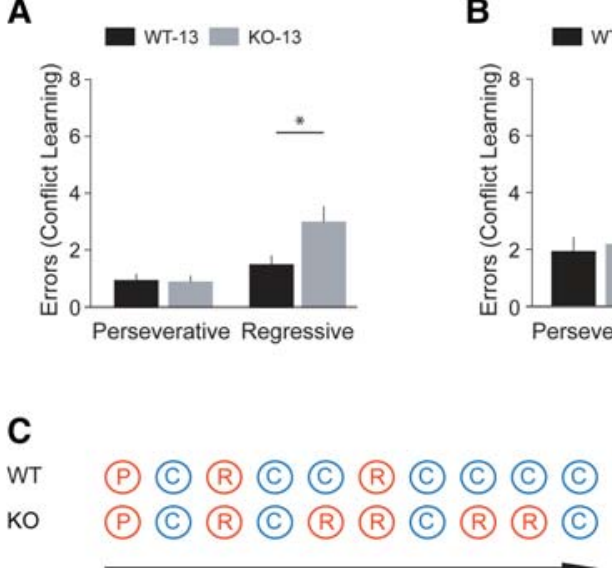

Sequence of consecutive choices

Figure 7. Types of error. Errors made to reach criterion were analyzed for Conflict Learning sessions 1 and 2 combined. $(A)$ In comparison with WT-13 animals, KO-13 mice committed a similar number of perseverative errors $(P=0.87)$ but a significantly higher number of regressive errors to reach criterion $(P=0.02)$. $(B)$ The number of perseverative errors was not significantly different between KO-B mice and WT-B mice $(P=0.72)$. The number of regressive errors made by KO-B mice was significantly higher than the number of those made by WT-B mice $(P=$ 0.02). $n=18$ for WT-13 and KO-13, $n=16$ for WT-B and KO-B. (C) The diagram illustrates the typical choice pattern and the types of error observed in $\mathrm{BC1} \mathrm{KO}$ and WT mice. $(\mathrm{P})$ perseverative error, $(\mathrm{R})$ regressive error, (C) correct choice.

as the ventral tegmental area (VTA), serve to negotiate resolution of conflicts between such expectancies and actual outcomes (Schoenbaum et al. 2009). Since BC1 RNA is expressed at high levels in prefrontal cortical regions and in the VTA of WT animals (Tiedge et al. 1991; Lin et al. 2001), lack of BC1 RNA repression may result in translational dysregulation in the OFC-VTA circuitry. One might therefore expect representation of outcome expectancies to dominate the resolution negotiations, with the result that in the case of changed contingencies, animal behavior will continue to be informed by such expectancies rather than by actual outcomes.

In mice, behavior has been shown to be impacted by the background strain type (Colacicco et al. 2002; Yoshiki and Moriwaki 2006; Bryant et al. 2008; Darnell 2014; Ishimura et al. 2014; Lei et al. 2014). We therefore considered it essential that all behavioral analyses be conducted with two $\mathrm{BC} 1 \mathrm{KO}$ animal strains with different genetic backgrounds. Thus, four groups of animals were used in this work: $\mathrm{KO}-13$ and $\mathrm{KO}-\mathrm{B}$, as well as their WT counterparts WT-13 and WT-B. Similarities as well as differences were noted concerning the performance of line 13 and line $\mathrm{B}$ animals. Both lines of $\mathrm{BC} 1 \mathrm{KO}$ animals were indistinguishable from WT animals in compound discrimination learning. Both lines of $\mathrm{BC} 1 \mathrm{KO}$ animals were significantly impaired in conflict learning, in comparison with WT animals, although performance improved with practice. Notably, however, line B animal performance was inferior to that of line 13 animals in most learning sessions, a statement that applies to both $\mathrm{KO}$ and WT mice of each strain. It thus appears that line $\mathrm{B}$ animals operate against a background of generally lower cognitive ability, in comparison with line 13 animals.

C57BL/6J mice (referred to as line B animals in this work) have been reported to be translationally dysregulated (Darnell 2014; Ishimura et al. 2014). As the underlying defect is a mutation in a brain-specific tRNA gene, it appeared plausible that phenotypic manifestations would include cognitive-behavioral impair- ments. This was in fact observed in our current work. We conclude that the use of $\mathrm{C} 57 \mathrm{BL} / 6 \mathrm{~J}$ animals may introduce a confound in the analysis of translation-dependent brain function. Interactions between the $\mathrm{C} 57 \mathrm{BL} / 6 \mathrm{~J}$ tRNA mutation and absence of BC1 RNA in the KO model may be complex and may involve elements of phenotypic exacerbation as well as occlusion. Our findings thus add to earlier concerns (Darnell 2014) regarding the "wild-type" RNA biology of this mouse strain.

The T-maze spatial task, in contrast to the ASST, did not reveal any significant performance differences between $\mathrm{KO}$ and WT animals of either strain. KO and WT animals alternated equally between the two goal arms as both tended to prefer the arm not visited in the previous trial. Thus, spontaneous spatial alternation appears intact in the absence of BC1 RNA. As such alternation is quite sensitive to dysfunction of the hippocampus (Deacon and Rawlins 2006), it is relevant to note that BC1 RNA is heterogeneously expressed in WT rodent brain (Tiedge et al. 1991; Lin et al. 2001). Expression levels in prefrontal cortical regions are among the highest in rodent brains (Tiedge et al. 1991; Lin et al. 2001), and one would therefore expect BC1 RNA translational regulation to play a significant role in prefrontal cortical-mediated cognition, as reported here. On the other hand, BC1 RNA expression levels in hippocampus are moderate to low, in particular in CA1 which has been implicated in spatial memory mechanisms (Tsien et al. 1996). Lack of BC1 RNA would therefore be predicted to precipitate milder, if any, deficits in hippocampus-mediated spatial behavioral performance. This is indeed the case as our work using the T-maze task and previous work using a series of spatial memory tasks (Lewejohann et al. 2004) revealed no impairment in hippocampal memory or cognition in the absence of BC1 RNA. Similarly, only minor spatial learning impairments were observed in the active place avoidance task, a behavioral paradigm that is exquisitely sensitive to even mild hippocampal dysfunction (Zhong et al. 2010). The combined evidence suggests that brain areas differ in their requirement for BC1 RNA control, a requirement that gives rise to differential cognitive impairments in the absence of the RNA.

Errors committed by $\mathrm{BC} 1 \mathrm{KO}$ animals in conflict learning sessions were predominantly of the regressive type. An animal would, after making at least one correct selection, regress back to making incorrect choices. Adaptive decision-making thus continued to be informed by outdated but dominant outcome expectancies (Fig. 9). Regression-type cognitive impairment and reduced behavioral flexibility have also been observed in a subset of ASD patients (Ozonoff et al. 1994, 2004; D'Cruz et al. 2013), and ASD-like phenotypes have been attributed to aberrant translational control in model animal neurons (Gkogkas et al. 2013; Santini

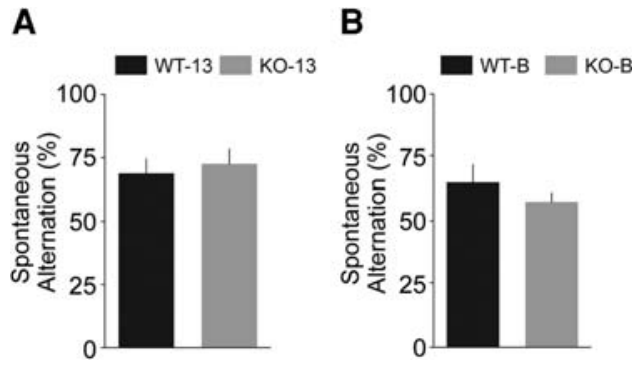

Figure 8. Spontaneous alternation in the T-maze. Alternation percentages were scored for line $13(A)$ and line $B(B)$ animals. No significant differences were observed between KO and WT animals of line $13(P=0.64)$ or line $B(P=0.75)$. There was also no significant difference between the performance of line 13 and line $B$ animals $(P=0.10) . n=8$ for each group. 
A Discrimination Learning

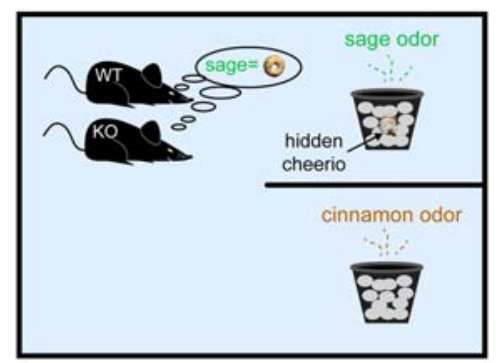

B

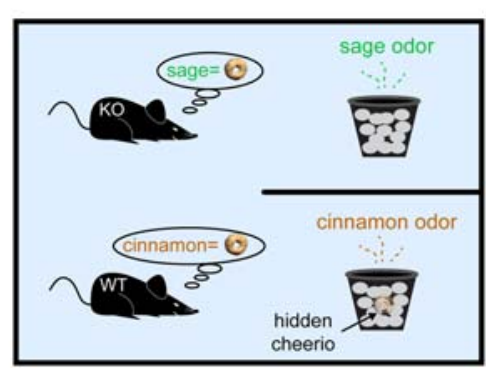

Figure 9. Impaired cognitive flexibility in the absence of regulatory $B C 1$ RNA. An attentional set shifting task (ASST) paradigm was used to ascertain memory and cognition in WT and KO animals. $(A)$ WT and KO animals performed equally well in Compound Discrimination Learning sessions as both were able to acquire and successfully apply an odor-based reward retrieval strategy. The animals had learned that sage odor was associated with a reward whereas cinnamon was not. $(B)$ In Conflict Learning sessions, animals were confronted with a novel situation. The odor-reward coupling was switched as cinnamon rather than sage had now become reward-associated. The novel scenario was thus in conflict with what the animals had learned before. WT animals quickly adjusted with a revised response strategy. In contrast, $\mathrm{KO}$ animals continued to apply the previously acquired strategy, i.e., trying to find a reward in the sage-scented bowl. Even after having found, by "chance," a reward in the cinnamonscented bowl (and having consumed it), a KO animal would regress back to the old but now inappropriate response strategy, expecting to find a reward in the sage-scented bowl. It thus appears that in the absence of BC1 RNA, animals rely on outdated but dominant outcome expectancies even after having experienced conflicting actual outcomes.

et al. 2013; Aguilar-Valles et al. 2015). In addition, regulatory nonprotein-coding RNAs have been associated with ASD. Regulatory RNAs were found expressed from ASD-related genomic regions (Velmeshev et al. 2013), and other such RNAs appear aberrantly expressed in ASD brains (Ziats and Rennert 2013). Our present work supports the thesis that RNA control of neuronal translation is a mechanistic underpinning of higher brain function that, if impaired, can result in cognitive deficits (Gkogkas et al. 2010; Darnell 2011).

\section{Materials and Methods}

\section{Animals}

Two lines of BC1 $\mathrm{KO}$ animals were used in this work: (i) $\mathrm{BC} 1^{-/-}$ line 13 animals of mixed C57BL/6J and 129X1/SvJ background (Skryabin et al. 2003), in the following called BC1 KO-13 mice, and (ii) $\mathrm{BC} 1^{-1-}$ animals backcrossed into the $\mathrm{C} 57 \mathrm{BL} / 6 \mathrm{~J}$ strain (>15 generations), in the following called BC1 KO-B mice. Corresponding wild-type (WT) animals were of respective identical background and are referred to as WT-13 and WT-B mice. Animals were bred in house. 8-12-wk-old male mice were used for behavioral assays. Animals were euthanized following completion of behavioral experiments.

Work with vertebrate animals was carried out in accordance with the Public Health Service Policy on Humane Care and Use of Laboratory Animals and was approved by the SUNY Downstate Medical Center (DMC) Institutional Animal Care and Use Committee.

\section{Self-grooming assay}

The two lines of $\mathrm{BC} 1 \mathrm{KO}$ mice and the respective lines of WT mice were scored for self-grooming behavioral as described (McFarlane et al. 2008). In brief, a mouse was placed in a clean empty box without bedding for $10 \mathrm{~min}$ of habituation time. The investigator, positioned $2 \mathrm{~m}$ from the test box, would then stopwatch-score, over a period of $10 \mathrm{~min}$, the cumulative time a mouse would spend spontaneously self-grooming.

\section{Attentional set shift task (ASST)}

The protocol was adopted from previous work (Colacicco et al. 2002; Garner et al. 2006; Scheggia et al. 2014; Tait et al. 2014) as follows.

Animals were trained in a plexiglass apparatus (shown in Fig. $10 A)$, custom-built at SUNY DMC. Inside the apparatus, a crosswise moveable divider gate separated the holding area (Starting Compartment) from the testing area. The testing area contained an immovable central divider that split the area lengthwise into two compartments. A removable plexiglass lid was used to prevent animals from escaping while undergoing trials.

Mice were restricted to $3 \mathrm{~g}$ of mashed food per day, beginning $1 \mathrm{wk}$ before initiation of the behavioral routines until they reached $90 \%$ of their ad libitum body weight, and continued on this restricted diet for the remainder of the testing period.

For habituation, an animal was given free access to the entire apparatus for $1 \mathrm{~h}$. Afterward, in three shaping sessions on the same day, the animal was trained to retrieve a food reward (a onefourth piece of honey-nut Cheerio-type cereal) from clay pots used as baiting bowls, one placed on either side of the central divider. Bowls were baited out of sight of animals to be tested. In the first shaping session, two bowls free of scent, digging medium, or excess texture, were baited and placed inside the testing area. The session was initiated with the mouse being placed inside the holding area and the gate being raised temporarily, allowing the animals entry into the testing area to retrieve bait from the bowls. After retrieval, the animal was moved back to the holding area and allowed to consume the reward. This step was repeated twice.

In a second shaping session, the bowls were filled with shredded tissue as a digging medium. The rewards were placed on top of the medium in each bowl. The mouse would retrieve rewards in three consecutive trials, after which the procedure concluded as described above. In the third shaping session, the bowls were filled with digging medium in which the rewards were buried. In three consecutive trials, the animal would retrieve the rewards by digging into the medium. In the subsequent training sessions, the mice were presented with up to three classes of discriminanda (henceforth referred to as "dimensions"): the textures of the bowl's outer surfaces, the digging media, and distinctive odors that marked the digging media.

Simple Discrimination (SD) Learning, Compound Discrimination (CD) Learning, and Conflict Learning sessions were performed in four phases over a 3-d period. The initial Simple Discrimination Learning session was performed on the same day as the habituation training (and is sometimes considered part of habituation training; Cao et al. 2012). In this session, the animal established that a specific trial dimension-e.g., odor-was the relevant discriminandum. We verified that the $\mathrm{KO}$ animals did not express inborn preferences for any of the odors that were used as stimuli in the trials. We monitored, for each $\mathrm{KO}$ animal tested, the choices made when initially presented with two novel odor options. We did not record any bias or preference for a particular odor. For example, in the Phase 1 Simple Discrimination 
A

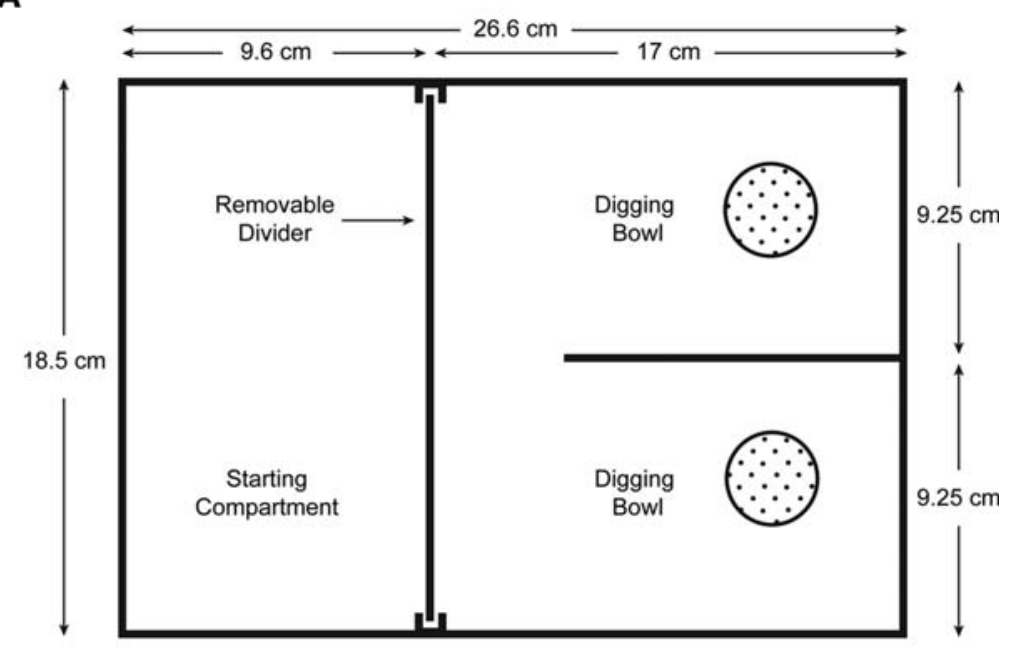

B

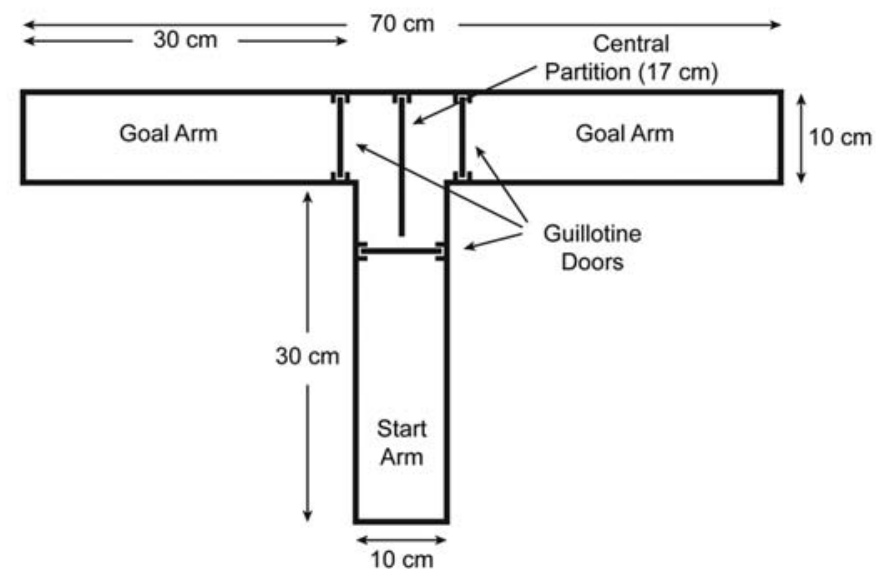

Figure 10. The two apparatuses used for behavioral tasks. (A) The apparatus used for the ASST paradigm is also known as the U-maze (Garner et al. 2006). (B) A T-maze was used to examine nonrewarded, spontaneous spatial alternation (Deacon and Rawlins 2006).

session, we observed no significant difference in the initial digging choices, i.e., sage-scented bowl versus cinnamon-scented bowl $(P=0.11$; not illustrated). Biased odor preferences were also not observed when animals were exposed to novel odor pairings in subsequent sessions, and we did not record any significant differences in the initial digging choices between KO and WT animals for the odors listed in Table 1 . Moreover, the fact that $\mathrm{KO}$ animal performance was not significantly different from WT animal performance in all four Compound Discrimination sessions indicates that olfaction was not impaired in $\mathrm{KO}$ animals.

All bowls were scented with crushed bait to mask the smell of the hidden bait. The bowl with the reward-predictive scent was baited with the food reward, hidden in the digging medium, and the bowl with the nonpredictive scent was left unbaited. We performed additional experiments to address the formal possibility that animals might still be able to detect the scent of the bait in the digging bowl. To this end, we modified the Phase 1 Simple Discrimination session to a catch-trial format in which the reward was not hidden in the bowl with the reward-predictive scent, but was dropped into that bowl after the animal had made the correct choice by digging in it. We did not observe any significant differences between catch-trial SD learning performance and standard SD learning performance for WT or KO animals $(P=0.61$ and $P=0.89$, respectively; not illustrated). On the basis of these results, we removed from consideration the possibility that an an- imal's bowl selection was affected by an ability to detect the bait by scent.

In Compound Discrimination Learning trials, performed on the following $2 \mathrm{~d}$, the two bowls were associated with two additional but reward-irrelevant dimensions (digging medium and bowl texture) that served as distractors (Jazbec et al. 2007). In Conflict Learning trials, a stimulus in a reward-relevant dimension (e.g., odor) was switched from reward-predictive to nonpredictive and vice versa.

Nine learning sessions were performed in four phases over $3 \mathrm{~d}$. The dimensions and stimuli that were applied in each of these sessions are listed in Table 1. In Phases 2 and 3, animals were subjected to changes in rewardpredictive and nonpredictive stimuli, but the reward-relevant dimension remained odor throughout (intradimensional shift, IDS). In Phase 4, the reward-relevant dimension was changed from odor to digging medium (extradimensional shift, EDS). At this stage, animals had to learn to discriminate on the basis of a reward-predictive stimulus in the new dimension and at the same time had to learn to disregard previous stimulus-reward couplings. Respective pairings of odors, media, and textures were maintained across groups of animals (Ng et al. 2007). To counterbalance valence of stimuli across animals, the reward-predictive stimulus of a relevant dimension was never paired with the same stimuli of the irrelevant dimensions in more than two consecutive trials. Such randomization across animals was applied in each of the nine sessions.

Placement of the two bowls was randomized and predetermined so animals could not use right-left cues to determine baited-bowl positioning. Bowls were simultaneously placed into position in the testing apparatus. For the first four trials of each session, the mouse was allowed to dig in both bowls to discover and consume the bait, but an error was recorded if an incorrect choice was made. The subsequent trials proceeded as follows. If the mouse made a correct choice, it was returned to the holding area and allowed to consume the bait. If it made an incorrect choice, the trial was terminated by removing the mouse and returning it to the holding area, i.e., not allowing it to search any further for bait. To successfully complete a learning session (i.e., to reach criterion), a mouse had to make at least eight correct choices in 10 consecutive trials. For each session, the investigator recorded the number of incorrect choices (errors to criterion, ETC) and the number of trials needed to complete the session (trials to criterion, TTC). Animals that did not reach criterion were excluded from analysis. If a mouse failed to dig within a 5-min period, the trial was terminated and the mouse returned to the holding area (and the failure recorded as an error). In case of three consecutive failures, the animal would be removed from the apparatus and returned to its home cage to resume testing the next day. After each trial, the apparatus was wiped clean with $2 \% \mathrm{NH}_{4} \mathrm{Cl}$ to remove odors.

Results from Phase 1 and Phase 2 Conflict Learning sessions were analyzed for the types of error committed (Baker et al. 2011; Amodeo et al. 2012). Errors were classified as perseverative if in its selection strategy, an animal would stick to a choice that was correct in the preceding session but had become incorrect in the current Conflict Learning session. Conversely, if an animal made at 
least one correct choice in a Conflict Learning session, any subsequent errors would be classified as regressive. In this case, the animal had applied the correct conflict learning strategy at least once but subsequently regressed to the previously correct but now inappropriate selection strategy.

\section{Spontaneous alternation}

T-maze experiments were performed as described (Deacon and Rawlins 2006). A T-shaped gray plastic maze (obtained from Maze Engineers) featured three arms, one start arm and two goal arms, as shown in Figure 10B. A central partition extended $7 \mathrm{~cm}$ into the start arm to prevent an animal, after entering the chosen goal arm, from sampling the opposite arm. The three arms were equipped with upward-sliding gates (also known as guillotine doors; Deacon and Rawlins 2006). Once an animal had chosen and entered a goal arm, the gate of that arm was lowered and the animal allowed to remain in place for $30 \mathrm{sec}$. The animal was then retrieved and repositioned in the start arm. After the central partition was removed and all gates were opened, the animal was allowed to make a second choice, and spontaneous alternation was recorded and scored as percentage of total goal arm entrances. We performed 10 trials per animal, with an inter-trial interval of $20 \mathrm{~min}$ (Deacon et al. 2003).

\section{Statistical analysis}

SAS version 9.4 (SAS Institute Inc.) was used for statistical analyses. We used the Cox proportional hazards regression model to analyze behavioral data (Jahn-Eimermacher et al. 2011). Two predictor variables, genotype (BC1 KO versus WT) and strain (line 13 versus line $\mathrm{B}$ ), along with their interaction, were used in comparing the number of ETC and TTC. ETC and TTC data were examined stratified for the type of learning session. The robust variance estimator (Lin and Wei 1989) was used to account for the correlated observations (ETC and TTC values) for each animal. Performance rates were compared between groups by examining their hazard ratio (HR). An $\mathrm{HR}<1$ indicates a poorer performance of the first group as more errors were committed and more trials are needed to reach criterion, in comparison with the second group. An HR $>1$ indicates better performance in the first group, relative to the second, and an $\mathrm{HR}=1$ indicates no performance difference between the groups. We preferred the Cox proportional hazards regression model over analysis of variance (ANOVA) because of the skewed distribution of the outcomes and the advantages of the former approach compared to the latter, as described elsewhere (Jahn-Eimermacher et al. 2011).

For learning curve analysis, we used the Jonckheere-Terpstra test for trend to examine whether the number of errors changed across phases for each group. The Mann-Whitney test was used to analyze self-grooming behavior in $\mathrm{KO}$ and WT genotypes. The Mann-Whitney test was also used to compare distributions of perseverative and regressive errors between $\mathrm{KO}$ and WT genotypes for lines 13 and B. Finally, the Mann-Whitney test was used to analyze spatial performance of KO versus WT animals in the T-maze task. Prism (GraphPad Software) was used to generate graphs. Data in the figures represent mean \pm standard error of the mean. Levels of significance are indicated in the figures as follows: $\left(^{*}\right) P<0.05,\left({ }^{* *}\right) P<0.01,\left({ }^{* * *}\right) P<0.001$.

\section{Acknowledgments}

This work was supported in part by NIH grants DA026110 and NS046769 (H.T.). We thank Dr. Ain Chung, Dr. André Fenton, and our colleagues at the Robert F. Furchgott Center for advice and discussion.

\section{References}

Aguilar-Valles A, Matta-Camacho E, Khoutorsky A, Gkogkas C, Nader K, Lacaille J-C, Sonenberg N. 2015. Inhibition of group I metabotropic glutamate receptors reverses autistic-like phenotypes caused by deficiency of the translation repressor eIF4E binding protein 2. J. Neurosci 35: 11125-11132.

Amaral PP, Dinger ME, Mercer TR, Mattick JS. 2008. The eukaryotic genome as an RNA machine. Science 319: 1787-1789.

Amodeo DA, Jones JH, Sweeney JA, Ragozzino ME. 2012. Differences in $\mathrm{BTBR} \mathrm{T}+\mathrm{tf} / \mathrm{J}$ and $\mathrm{C} 57 \mathrm{BL} / 6 \mathrm{~J}$ mice on probabilistic reversal learning and stereotyped behaviors. Behav Brain Res 227: 64-72.

Baker PM, Thompson JL, Sweeney JA, Ragozzino ME. 2011. Differential effects of $5-\mathrm{HT}_{2 \mathrm{~A}}$ and $5-\mathrm{HT}_{2 \mathrm{C}}$ receptor blockade on strategy-switching. Behav Brain Res 219: 123-131.

Birney E, Stamatoyannopoulos JA, Dutta A, Guigo R, Gingeras TR, Margulies EH, Weng Z, Snyder M, Dermitzakis ET, Thurman RE, et al. 2007. Identification and analysis of functional elements in $1 \%$ of the human genome by the ENCODE pilot project. Nature 447: 799-816.

Brosius J. 2014. The persistent contributions of RNA to eukaryotic gen(om)e architecture and cellular function. Cold Spring Harb Perspect Biol 6: a016089.

Brown VJ, Bowman EM. 2002. Rodent models of prefrontal cortical function. Trends Neurosci 25: 340-343.

Bryant CD, Zhang NN, Sokoloff G, Fanselow MS, Ennes HS, Palmer AA, McRoberts JA. 2008. Behavioral differences among C57BL/ 6 substrains: implications for transgenic and knockout studies. J Neurogenet 22: 315-331.

Cao X, Yeo G, Muotri AR, Kuwabara T, Gage FH. 2006. Noncoding RNAs in the mammalian central nervous system. Annu Rev Neurosci 29: 77-103.

Cao A-H, Yu L, Wang Y-W, Wang J-M, Yang L-J, Lei G-F. 2012. Effects of methylphenidate on attentional set-shifting in a genetic model of attention-deficit/hyperactivity disorder. Behav Brain Funct 8: 1-10.

Chicurel ME, Terrian DM, Potter H. 1993. mRNA at the synapse: analysis of a preparation enriched in hippocampal dendritic spines. J Neurosci 13: 4054-4063.

Cho RY, Konecky RO, Carter CS. 2006. Impairments in frontal cortical $\gamma$ synchrony and cognitive control in schizophrenia. Proc Natl Acad Sci 103: $19878-19883$.

Cho KK, Hoch R, Lee AT, Patel T, Rubenstein JL, Sohal VS. 2015. $\gamma$ Rhythms link prefrontal interneuron dysfunction with cognitive inflexibility in Dlx5/6(+/-) mice. Neuron 85: 1332-1343.

Colacicco G, Welzl H, Lipp HP, Wurbel H. 2002. Attentional set-shifting in mice: modification of a rat paradigm, and evidence for strain-dependent variation. Behav Brain Res 132: 95-102.

Cordaux R, Batzer MA. 2009. The impact of retrotransposons on human genome evolution. Nat Rev Genet 10: 691-703.

Darnell JC. 2011. Defects in translational regulation contributing to human cognitive and behavioral disease. Curr Opin Genet Dev 21: $465-473$.

Darnell JC. 2014. Ribosome rescue and neurodegeneration. Science 345: 378-379.

D'Cruz AM, Ragozzino ME, Mosconi MW, Shrestha S, Cook EH, Sweeney JA. 2013. Reduced behavioral flexibility in autism spectrum disorders. Neuropsychology 27: 152-160.

Deacon RM, Rawlins JN. 2006. T-maze alternation in the rodent. Nat Protoc 1: $7-12$.

Deacon RM, Penny C, Rawlins JN. 2003. Effects of medial prefrontal cortex cytotoxic lesions in mice. Behav Brain Res 139: 139-155.

Dias R, Robbins TW, Roberts AC. 1997. Dissociable forms of inhibitory control within prefrontal cortex with an analog of the Wisconsin Card Sort Test: restriction to novel situations and independence from "on-line" processing. J Neurosci 17: 9285-9297.

Djebali S, Davis CA, Merkel A, Dobin A, Lassmann T, Mortazavi A, Tanzer A, Lagarde J, Lin W, Schlesinger F, et al. 2012. Landscape of transcription in human cells. Nature 489: 101-108.

Dmitriev SE, Terenin IM, Dunaevsky YE, Merrick WC, Shatsky IN. 2003. Assembly of $48 \mathrm{~S}$ translation initiation complexes from purified components with mRNAs that have some base pairing within their $5^{\prime}$ untranslated regions. Mol Cell Biol 23: 8925-8933.

Eichenbaum H, Clegg RA, Feeley A. 1983. Reexamination of functional subdivisions of the rodent prefrontal cortex. Exp Neurol 79: 434-451.

Eom T, Berardi V, Zhong J, Risuleo G, Tiedge H. 2011. Dual nature of translational control by regulatory BC RNAs. Mol Cell Biol 31: 4538-4549.

Eom T, Muslimov IA, Tsokas P, Berardi V, Zhong J, Sacktor TC, Tiedge H. 2014. Neuronal BC RNAs cooperate with eIF4B to mediate activity-dependent translational control. J Cell Biol 207: 237-252.

Fries P. 2009. Neuronal $\gamma$-band synchronization as a fundamental process in cortical computation. Annu Rev Neurosci 32: 209-224.

Garner JP, Thogerson CM, Wurbel H, Murray JD, Mench JA. 2006. Animal neuropsychology: validation of the intra-dimensional extra-dimensional set shifting task for mice. Behav Brain Res 173: $53-61$.

Gkogkas C, Sonenberg N, Costa-Mattioli M. 2010. Translational control mechanisms in long-lasting synaptic plasticity and memory. J Biol Chem 285: 31913-31917. 
Gkogkas CG, Khoutorsky A, Ran I, Rampakakis E, Nevarko T, Weatherill DB, Vasuta C, Yee S, Truitt M, Dallaire P, et al. 2013. Autism-related deficits via dysregulated eIF4E-dependent translational control. Nature 493: 371-377.

Gruber AJ, Calhoon GG, Shusterman I, Schoenbaum G, Roesch MR, O'Donnell P. 2010. More is less: a disinhibited prefrontal cortex impairs cognitive flexibility. J Neurosci 30: 17102-17110.

Iacoangeli A, Tiedge H. 2013. Translational control at the synapse: role of RNA regulators. Trends Biochem Sci 38: 47-55.

Ishimura R, Nagy G, Dotu I, Zhou H, Yang XL, Schimmel P, Senju S, Nishimura Y, Chuang JH, Ackerman SL. 2014. Ribosome stalling induced by mutation of a CNS-specific tRNA causes neurodegeneration. Science 345: 455-459.

Jahn-Eimermacher A, Lasarzik I, Raber J. 2011. Statistical analysis of latency outcomes in behavioral experiments. Behav Brain Res 221: 271-275.

Jazbec S, Pantelis C, Robbins T, Weickert T, Weinberger DR, Goldberg TE. 2007. Intra-dimensional/extra-dimensional set-shifting performance in schizophrenia: impact of distractors. Schizophr Res 89: 339-349.

Lai MC, Lombardo MV, Baron-Cohen S. 2014. Autism. Lancet 383: $896-910$

Lalonde R. 2002. The neurobiological basis of spontaneous alternation. Neurosci Biobehav Rev 26: 91-104.

Lee H, Dvorak D, Kao HY, Duffy AM, Scharfman HE, Fenton AA. 2012. Early cognitive experience prevents adult deficits in a neurodevelopmental schizophrenia model. Neuron 75: 714-724.

Lei P, Ayton S, Moon S, Zhang Q, Volitakis I, Finkelstein DI, Bush AI. 2014. Motor and cognitive deficits in aged tau knockout mice in two background strains. Mol Neurodegen 9: 29.

Lewejohann L, Skryabin BV, Sachser N, Prehn C, Heiduschka P, Thanos S, Jordan U, Dell'Omo G, Vyssotski AL, Pleskacheva MG, et al. 2004. Role of a neuronal small non-messenger RNA: behavioural alterations in BC1 RNA-deleted mice. Behav Brain Res 154: 273-289.

Lin DY, Wei LJ. 1989. The robust interference for the proportional hazards model. J Am Stat Assoc 84: 1074-1078.

Lin Y, Brosius J, Tiedge H. 2001. Neuronal BC1 RNA: co-expression with growth-associated protein-43 messenger RNA. Neuroscience 103: 465-479.

Lin D, Pestova TV, Hellen CU, Tiedge H. 2008. Translational control by a small RNA: dendritic BC1 RNA targets the eukaryotic initiation factor 4A helicase mechanism. Mol Cell Biol 28: 3008-3019.

Mattick JS. 2004. RNA regulation: a new genetics? Nat Rev Genet 5: 316-323.

Mattick JS. 2009. The genetic signatures of noncoding RNAs. PLoS Genet 5: e1000459.

McAlonan K, Brown VJ. 2003. Orbital prefrontal cortex mediates reversal learning and not attentional set shifting in the rat. Behav Brain Res 146: 97-103.

McFarlane HG, Kusek GK, Yang M, Phoenix JL, Bolivar VJ, Crawley JN. 2008. Autism-like behavioral phenotypes in BTBR T $+\mathrm{tf} / \mathrm{J}$ mice. Genes Brain Behav 7: 152-163.

Muslimov IA, Santi E, Homel P, Perini S, Higgins D, Tiedge H. 1997. RNA transport in dendrites: a cis-acting targeting element is contained within neuronal BC1 RNA. J Neurosci 17: 4722-4733.

Muslimov IA, Iacoangeli A, Brosius J, Tiedge H. 2006. Spatial codes in dendritic BC1 RNA. J Cell Biol 175: 427-439.

Muslimov IA, Patel MV, Rose A, Tiedge H. 2011. Spatial code recognition in neuronal RNA targeting: Role of RNA-hnRNP A2 interactions. J Cell Biol 194: 441-457.

Ng CW, Noblejas MI, Rodefer JS, Smith CB, Poremba A. 2007. Double dissociation of attentional resources: prefrontal versus cingulate cortices. J Neurosci 27: 12123-12131.

Ozonoff S, Strayer DL, McMahon WM, Filloux F. 1994. Executive function abilities in autism and Tourette syndrome: an information processing approach. J Child Psychol Psychiatry 35: 1015-1032.

Ozonoff S, Cook I, Coon H, Dawson G, Joseph RM, Klin A, McMahon WM, Minshew N, Munson JA, Pennington BF, et al. 2004. Performance on Cambridge Neuropsychological Test Automated Battery subtests sensitive to frontal lobe function in people with autistic disorder: evidence from the Collaborative Programs of Excellence in Autism network. J Autism Dev Disord 34: 139-150.

Pestova T, Lorsch JR, Hellen CUT. 2007. The mechanism of translation initiation in eukaryotes. In Translational control in biology and medicine (ed. Mathews MB, Sonenberg N, Hershey JWB), pp. 87-128. Cold Spring Harbor Laboratory Press, Cold Spring Harbor, NY.

Phillips WA, Silverstein SM. 2003. Convergence of biological and psychological perspectives on cognitive coordination in schizophrenia. Behav Brain Sci 26: 65-82; discussion 82-137.
Ragozzino ME. 2007. The contribution of the medial prefrontal cortex, orbitofrontal cortex, and dorsomedial striatum to behavioral flexibility. Ann N Y Acad Sci 1121: 355-375.

Ragozzino ME, Jih J, Tzavos A. 2002. Involvement of the dorsomedial striatum in behavioral flexibility: role of muscarinic cholinergic receptors. Brain Res 953: 205-214.

Rawlins JN, Olton DS. 1982. The septo-hippocampal system and cognitive mapping. Behav Brain Res 5: 331-358.

Salta E, De Strooper B. 2012. Non-coding RNAs with essential roles in neurodegenerative disorders. Lancet Neurol 11: 189-200.

Santini E, Huynh TN, MacAskill AF, Carter AG, Pierre P, Ruggero D, Kaphzan H, Klann E. 2013. Exaggerated translation causes synaptic and behavioural aberrations associated with autism. Nature 493: 411-415.

Scheggia D, Bebensee A, Weinberger DR, Papaleo F. 2014. The ultimate intra-/extra-dimensional attentional set-shifting task for mice. Biol Psychiatry 75: 660-670.

Schoenbaum G, Nugent SL, Saddoris MP, Setlow B. 2002. Orbitofrontal lesions in rats impair reversal but not acquisition of go, no-go odor discriminations. Neuroreport 13: 885-890.

Schoenbaum G, Roesch MR, Stalnaker TA, Takahashi YK. 2009. A new perspective on the role of the orbitofrontal cortex in adaptive behaviour. Nat Rev Neurosci 10: 885-892.

Shahbazian D, Parsyan A, Petroulakis E, Hershey J, Sonenberg N. 2010. eIF4B controls survival and proliferation and is regulated by proto-oncogenic signaling pathways. Cell Cycle 9: 4106-4109.

Silverman JL, Tolu SS, Barkan CL, Crawley JN. 2010. Repetitive self-grooming behavior in the BTBR mouse model of autism is blocked by the mGluR5 antagonist MPEP. Neuropsychopharmacology 35: 976-989.

Skryabin BV, Sukonina V, Jordan U, Lewejohann L, Sachser N, Muslimov I, Tiedge H, Brosius J. 2003. Neuronal untranslated BC1 RNA: targeted gene elimination in mice. Mol Cell Biol 23: 6435-6441.

Taft RJ, Pheasant M, Mattick JS. 2007. The relationship between non-protein-coding DNA and eukaryotic complexity. Bioessays 29: 288-299.

Tait DS, Chase EA, Brown VJ. 2014. Attentional set-shifting in rodents: a review of behavioural methods and pharmacological results. Cur Pharm Des 20: 5046-5059.

Tiedge H, Fremeau RT Jr, Weinstock PH, Arancio O, Brosius J. 1991. Dendritic location of neural BC1 RNA. Proc Natl Acad Sci 88: 2093-2097.

Tiedge H, Chen W, Brosius J. 1993. Primary structure, neural-specific expression, and dendritic location of human BC200 RNA. J Neurosci 13: $2382-2390$.

Tsien JZ, Huerta PT, Tonegawa S. 1996. The essential role of hippocampal CA1 NMDA receptor-dependent synaptic plasticity in spatial memory. Cell 87: $1327-1338$.

Uhlhaas PJ, Singer W. 2006. Neural synchrony in brain disorders: relevance for cognitive dysfunctions and pathophysiology. Neuron 52: 155-168.

Uhlhaas PJ, Singer W. 2007. What do disturbances in neural synchrony tell us about autism? Biol Psychiatry 62: 190-191.

Uhlhaas PJ, Singer W. 2012. Neuronal dynamics and neuropsychiatric disorders: toward a translational paradigm for dysfunctional large-scale networks. Neuron 75: 963-980.

Velmeshev D, Magistri M, Faghihi MA. 2013. Expression of non-protein-coding antisense RNAs in genomic regions related to autism spectrum disorders. Mol Autism 4: 32 .

Wang H, Iacoangeli A, Popp S, Muslimov IA, Imataka H, Sonenberg N, Lomakin IB, Tiedge H. 2002. Dendritic BC1 RNA: functional role in regulation of translation initiation. J Neurosci 22: 10232-10241.

Wang H, Iacoangeli A, Lin D, Williams K, Denman RB, Hellen CUT, Tiedge H. 2005. Dendritic BC1 RNA in translational control mechanisms. J Cell Biol 171: 811-821.

Yoshiki A, Moriwaki K. 2006. Mouse phenome research: implications of genetic background. ILAR J 47: 94-102.

Zhong J, Chuang SC, Bianchi R, Zhao W, Lee H, Fenton AA, Wong RK, Tiedge H. 2009. BC1 regulation of metabotropic glutamate receptor-mediated neuronal excitability. J Neurosci 29: 9977-9986.

Zhong J, Chuang SC, Bianchi R, Zhao W, Paul G, Thakkar P, Liu D, Fenton AA, Wong RK, Tiedge H. 2010. Regulatory BC1 RNA and the fragile $\mathrm{X}$ mental retardation protein: convergent functionality in brain. PLoS One 5: e15509.

Ziats MN, Rennert OM. 2013. Aberrant expression of long noncoding RNAs in autistic brain. J Mol Neurosci 49: 589-593.

Received February 28, 2017; accepted in revised form April 12, 2017. 


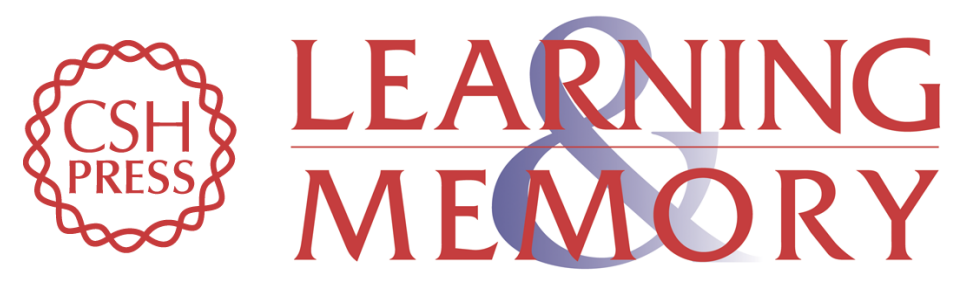

\section{Regulatory BC1 RNA in cognitive control}

Anna lacoangeli, Aderemi Dosunmu, Taesun Eom, et al.

Learn. Mem. 2017, 24:

Access the most recent version at doi:10.1101//m.045427.117

References This article cites 80 articles, 24 of which can be accessed free at: http://learnmem.cshlp.org/content/24/7/267.full.html\#ref-list-1

Creative This article is distributed exclusively by Cold Spring Harbor Laboratory Press for the Commons first 12 months after the full-issue publication date (see

License http://learnmem.cshlp.org/site/misc/terms.xhtml). After 12 months, it is available under a Creative Commons License (Attribution-NonCommercial 4.0 International), as described at http://creativecommons.org/licenses/by-nc/4.0/.

Email Alerting Receive free email alerts when new articles cite this article - sign up in the box at the Service top right corner of the article or click here. 